\title{
Carrot by-product fermentation quality and aerobic spoilage could be modified with silage additives
}

\author{
Marketta Rinne, Marcia Franco, Taina Jalava, Eila Järvenpää, Minna Kahala, Lucia Blasco, \\ Hilkka Siljander-Rasi and Kaisa Kuoppala \\ Production systems, Natural Resources Institute Finland (Luke), Finland \\ e-mail: marketta.rinne@luke.fi
}

\begin{abstract}
Vegetable by-products could potentially be suitable to be used as feeds in animal diets, which in general would strengthen the sustainability of both food and feed systems. Two experiments were performed with the objective to evaluate the aerobic spoilage via visual inspection and short term ensiling process of carrot by-products with silage additives (lactic acid bacteria [LAB] inoculants or formic acid [FA]). In the first experiment (Exp. 1), carrot by-product was treated with five additives including a control without additive, two commercial LAB inoculants (heterofermentative and homofermentative), an in-house isolated LAB mixture and a commercial FA based product. Second experiment (Exp. 2) used a $2 \times 3$ factorial design (type of raw material [carrot by-product with or without pieces] and additive treatment [control, heterofermentative LAB inoculant or FA based product]). Use of FA restricted lactic acid fermentation indicated by the high residual water soluble carbohydrate concentration while simultaneously stimulating ethanol production. LAB inoculants were not able to efficiently affect quality of ensiled carrot by-products. Use of FA also delayed the spoilage of the fresh carrot by-product particularly in Exp. 1.
\end{abstract}

Key words: Daucus carota, feed preservation, feed value, formic acid, lactic acid bacteria, vegetable waste

\section{Introduction}

Incremental demand in consumer choices and growth of population result in large quantities of biowaste worldwide (Karak et al. 2012). There is a requirement for a more sustainable production in the food industry, where many by-products become biowaste along the process chain. The food waste is an economic and ethical problem, and it also diminishes the natural resources, which are limited in the environment. According to Stenmarck et al. (2016), about 88 million tons of food waste is generated in the entire food chain of Europe including both edible food and inedible parts associated with food. This waste represents about $20 \%$ of the total food produced and the sectors contributing the most to food waste are households and processing. When it comes only to fruit and vegetable industry, the waste is even greater and according to FAO (Wadhwa and Bakshi 2013, Bakshi et al. 2016 ) it can reach nearly $50 \%$, with losses occurring during agricultural production, processing, distribution and in households. The production of vegetables is typically seasonal, and in many cases they are processed by small or medium size companies resulting in rather small batches of side streams, which makes efficient utilization of them challenging.

Food by-products have been an important source of feed for livestock throughout history and interest in even more efficient use of by-products and side streams is encouraged by economic and environmental incentives. Vegetable by-products could potentially be suitable to be used as feed in animal diets, which in general would strengthen the sustainability of both food and feed systems. According to Vasta et al. (2008), the inclusion of agro-industrial by-products in ruminant diets may be of interest for reducing feeding costs and diminishing environmental impacts associated with by-product accumulation. Two options for enhancing availability of feedstuffs are, firstly, efficient use of available feed resources and secondly, enlargement of the feed resource base, especially focusing on those feed resources that do not compete with human food (Bakshi et al. 2016). Schader et al. (2015) also suggested several strategies to increase sustainability in livestock production, including the reduction of the use of food-competing feed components in livestock rations, which also affects the availability of livestock products. This strategy shifts the focus from livestock's role in the food system as a source for high-quality protein, to another role, such as to use resources that cannot otherwise be used for food production.

Vegetable residues can be composted and used as soil amendment, or used in biogas production, but they result in only limited added value to the end product. A higher added value option would be to use them as animal feeds. This is challenging as vegetable residues are typically wet, easily perishable and prone to fast deterioration, which poses problems for the use of them as fresh as well as for preservation (Meneses et al. 2007, Vasta et al. 2008, Arco-Pérez et al. 2017). 
In farm conditions, the farmers would typically take the by-product from the company and almost immediately use it. It is not a type of material that will be preserved for long periods, such as in the case of grass silage because the supply of by-products is rather constant along the year, contrary to grass production. The extension of the shelf life up to one month is already very reasonable in terms of providing time for farmers to use it as animal feed. Furthermore, the most intense fermentation and possibly spoilage happens in the beginning of the storage period, so improvement of stability is needed especially during the first weeks of storage.

Additives can be added to materials to preserve and/or enhance the quality, such as increasing aerobic stability (Orosz and Davies 2015). Furthermore, the use of vegetable by-products as animal feed should bring benefits in terms of nutrient utilization, level of production reached, and provide safe feed to protect animal health, occupational health of the animal caretakers and finally the well-being of consumers using the animal products. However, developing an economically efficient process including logistic costs may be challenging (Adler et al. 2017). To be able to recycle these residues back into the food chain requires high hygienic quality of the products and good stability to allow efficient logistics.

Carrots are widely used as food and remarkable amounts of carrot by-products, such as peels and discarded carrots are generated. They are rich in sugar making them very palatable and traditionally, they have been used as a supplemental feed for horses. They are also readily consumed by ruminants and fit well e.g. in total mixed ration (TMR) for growing cattle. Muller et al. (1984) reported several on-farm examples where carrots were fed successfully to lactating dairy cows. Antone et al. (2015) studying the effect of feeding seven kg per day of carrots to dairy cows found an increase in carotene concentration in blood as well as $30 \%$ higher $\alpha$-tocopherol concentration and more intense yellow colour of butter resulting in improved cow health and product quality. Nalęcz-Tarwacka et al. (2003) reported an increase of Vitamin A and conjugated linoleic acid concentrations in milk of cows fed five $\mathrm{kg}$ of carrot daily. Carrots were included at $40 \%$ on dry matter (DM) basis in the diet of steers without adverse effects (Rust and Buskirk 2008).

The lack of knowledge in extension of shelf life of fresh carrot by-products as well as of preservation of them by fermentation motivated this research. Our hypothesis was that shelf-life of fresh carrot by-products can be prolonged and fermentation quality of preserved carrot by-products improved with the use of silage additives. Two experiments were performed with the objective to evaluate the stability of fresh carrot by-product and the ensiling process with or without commercial silage additives (lactic acid bacteria [LAB] inoculants and formic acid [FA] based additives) on chemical composition, fermentation pattern and aerobic spoilage.

\section{Materials and methods}

\section{Experiment 1}

In the first experiment (Exp. 1), washed and heated carrot by-product from steam-peeling was ensiled within 8 hours after processing. Five additive treatments were used including a control without additive, two commercial lactic acid bacteria (LAB) inoculants (heterofermentative [LAB1]; Bonsilage alfa, $2.5 \times 10^{5} \mathrm{cfu} \mathrm{g}^{-1}$; Schaumann, Pinneberg, Germany) and homofermentative [LAB2]; Josilac Classic, $6 \times 10^{5} \mathrm{cfu} \mathrm{g}^{-1}$; Kleinheubach, Germany), an in-house isolated LAB mixture [LAB3]; Luke, ca. $1 \times 10^{6} \mathrm{cfu} \mathrm{g}^{-1}$; Jokioinen, Finland) and a commercial formic acid-based additive (FA; AIV2 Plus, 5 I ton ${ }^{-1}$; Eastman Chemical Company, Oulu, Finland). Details of the additives are presented in Table 1.

The carrot mass was ensiled in 3 replicates in 1.5-I glass jars (average weight of fresh carrot mass 1685 g/jar), which were allowed to ferment for 28 days. Further, $100 \mathrm{ml}$ glass bottles (average weight of fresh carrot mass $118 \mathrm{~g} /$ bottle) were used to evaluate dynamics of fermentation. Three replicates for each additive treatment were prepared for 0 (use as fresh), 2, 6, 14 and 28 day fermentation periods to evaluate aerobic spoilage at different time points. Microbiological quality was evaluated in the raw material (day 0), in the bottles (days 2, 6 and 14) and in the jars (day 28). Additional three replicates were used to manually measure gas production from the bottles using a syringe to produce cumulative gas production curves over the 28-day ensiling period. All silages were kept in a temperature controlled room at $20^{\circ} \mathrm{C}$. After opening the $1.5 \mathrm{I}$ jars, solid and liquid fractions of the ensiled carrot by-product were separated by free draining using a funnel, where no force was applied to separate fractions, but only the gravity. 


\section{Experiment 2}

The second experiment (Exp. 2) had a factorial $2 \times 3$ design, where first factor was the type of raw material (carrot by-product with pieces and without pieces) and the second factor was the additive treatment (control without additive, LAB1 and FA). Carrot by-product contained peels and discarded pieces of carrot (with pieces) and also raw material with pieces removed was studied (without pieces). The carrot without pieces was processed the day before while the carrot with pieces was ensiled immediately after processing.

Table 1. Description of the silage additives used in the carrot ensiling experiments

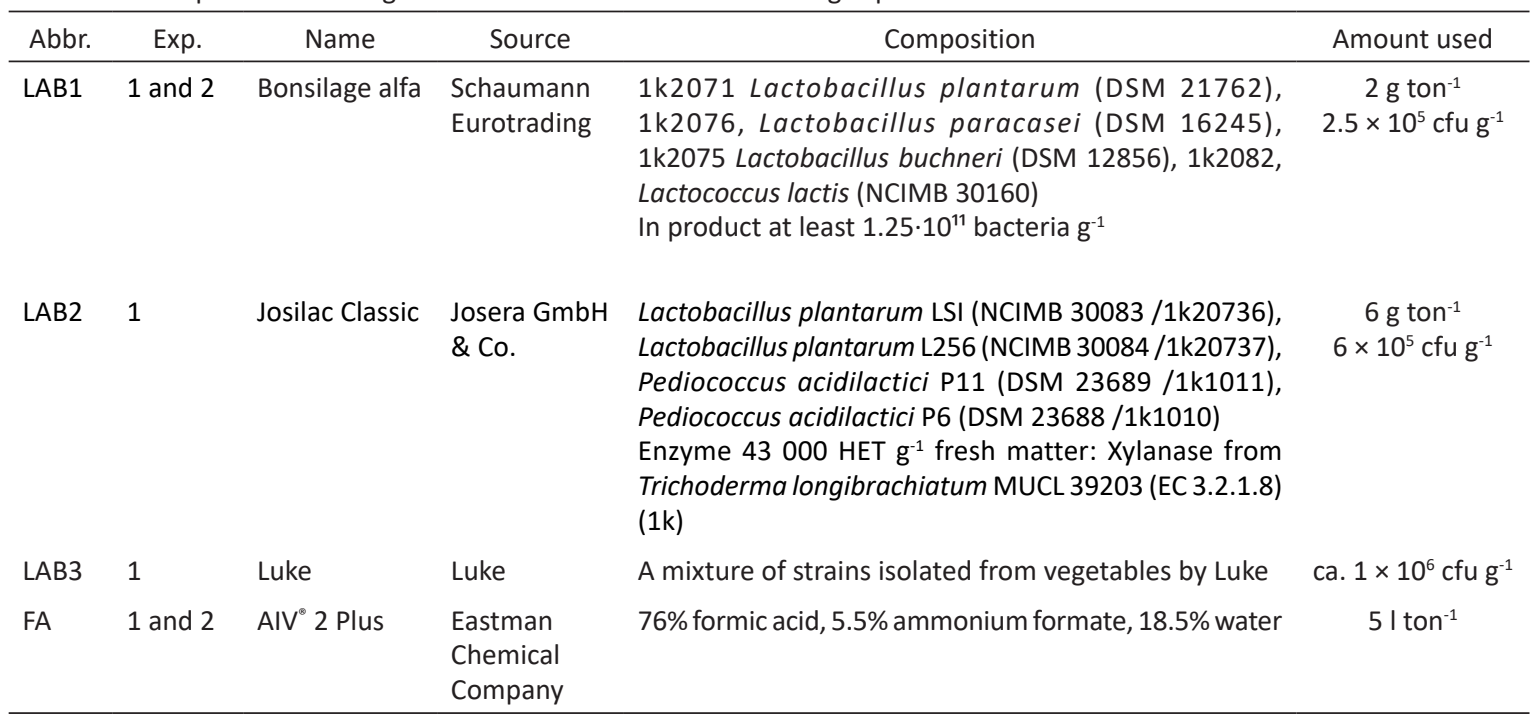

The carrot mass was carefully mixed with the additive and packed tightly in plastic bags (10 kg fresh matter), which were placed in buckets. Two replicates per treatment were prepared and stored in room temperature with average of $25^{\circ} \mathrm{C}$. The plastic bags were tightly sealed and a gas valve was placed on top of the bag to allow the gas escape. The bags were opened after a 3-week preservation period. Deteriorated parts were discarded prior to mixing and sampling for analyses.

Chemical analyses and aerobic spoilage

The DM, pH, ash, CP, WSC, ethanol (Exp. 1), NDF, proportion of ammonia $\mathrm{N}$ in total $\mathrm{N}$ and fermentation acids were analysed as presented by Seppälä et al. (2016). The N content of the original material was used to express ammonia- $\mathrm{N}$ proportions in total $\mathrm{N}$ after fermentation. For FA treated samples, ammonia was delivered in the form of ammonium formate. The added ammonia $\mathrm{N}$ was corrected for the ammonia $\mathrm{N}$ levels presented for ensiled carrot. Due to lack of material, water soluble carbohydrates (WSC) of the liquid fraction were analysed from samples combined across replicates. Carrot samples were analysed for enterobacteria, LAB, yeasts and moulds. For the microbiological analyses $25 \mathrm{~g}$ of sample was weighed, diluted with $225 \mathrm{ml}$ of $1 / 4$ strength Ringer solution (Merck, Germany) and homogenized for $1 \mathrm{~min}$ at $260 \mathrm{rpm}$ in a Stomacher 400 circulator (Seward Ltd, UK). Serial dilutions were plated on the respective cultivation media. Yeasts and moulds were enumerated on DRBC agar medium (Neogen, UK) supplemented with $50 \mathrm{\mu g} \mathrm{ml}^{-1}$ of oxytetracycline hydrochloride (AppliChem BioChemica, Germany) at $25^{\circ} \mathrm{C}$. Colonies were counted after 3 and 5 days of cultivation. Enterobacteria were determined on Violet red bile glucose agar (Neogen, UK) and cultivated for 1 day at $37^{\circ} \mathrm{C}$. The counts of lactic acid bacteria were enumerated by cultivation on MRS medium (BD, France) anaerobically at $30^{\circ} \mathrm{C}$ for 3 days.

\section{Visual inspection of aerobic spoilage}

Aerobic spoilage was measured by placing a $2 \mathrm{~cm}$ layer of the carrot mass in a plastic container which was covered by a perforated plastic film and maintained at $20^{\circ} \mathrm{C}$. Aerobic spoilage was evaluated once daily by visually observing growth of yeasts and moulds on the surface of the carrot mass using a scale: $0=$ no mould, $1=$ slight mouldiness, 2 = mouldiness, 3 = severe mouldiness. Once the sample was deteriorated, it was removed and the time was recorded as a result of the stability in days. In Exp. 1, fresh carrot by-product was used (day 0 ) as well as ensiled material after 2, 6, 14 and 28 days of fermentation. For Exp. 2, aerobic spoilage was observed for fresh and ensiled ( 21 days) carrot by-products. 


\section{Statistical analyses}

Data was analysed using a MIXED procedure (SAS Inc. 2002-2012, Release 9.4; SAS Inst., Inc., Cary, NC) of SAS at $5 \%$ of probability with treatment as fixed effect and replicates were taken as a random effect into the model. In Exp. 1 the sum of square was further partitioned into contrasts: control versus all LAB treatments; control versus FA; and all LAB treatments versus FA. In Exp. 2 the sum of square was partitioned into contrasts: raw material effect (carrot with pieces versus carrot without pieces); control versus LAB1; control versus FA; and LAB1 versus FA. Aerobic spoilage was presented as descriptive data.

\section{Results}

\section{Experiment 1}

The carrot by-product contained less DM ( 87 vs. $120 \mathrm{~g} \mathrm{~kg}^{-1}$ ) and ash ( $48 \mathrm{vs.} 80 \mathrm{~g} \mathrm{~kg}^{-1} \mathrm{DM}$ ) than the reference values in the Feed Tables (Luke 2019), but crude protein (CP; 93 vs. $100 \mathrm{~g} \mathrm{~kg}^{-1} \mathrm{DM}$ ) concentration was quite similar (Table 2).

Table 2. Composition and microbial quality of the carrot by-products before ensiling

\begin{tabular}{|c|c|c|c|}
\hline & \multirow{2}{*}{$\frac{\text { Exp. } 1}{\text { Carrot by-product }}$} & \multicolumn{2}{|c|}{ Exp. 2} \\
\hline & & Carrot with pieces & Carrot without pieces \\
\hline Dry matter (DM), $\mathrm{g} \mathrm{kg}^{-1}$ & 87 & 76 & 70 \\
\hline \multicolumn{4}{|l|}{ In DM, $\mathrm{g} \mathrm{kg}^{-1}$} \\
\hline Ash & 48 & 69 & 71 \\
\hline Crude protein & 93 & 65 & 68 \\
\hline Water soluble carbohydrates & 501 & 282 & 106 \\
\hline Neutral detergent fibre & 177 & 220 & 290 \\
\hline \multicolumn{4}{|l|}{ Feed values for ruminants } \\
\hline IVOMD, $\mathrm{g} \mathrm{g}^{-1}$ & 0.877 & 0.926 & 0.914 \\
\hline Metabolizable energy, $\mathrm{MJ} \mathrm{kg}^{-1} \mathrm{DM}$ & 13.4 & 13.8 & 13.6 \\
\hline MP, $\mathrm{g} \mathrm{kg}^{-1} \mathrm{DM}$ & 94 & 94 & 93 \\
\hline PBV, $\mathrm{g} \mathrm{kg}^{-1} \mathrm{DM}$ & -50 & -74 & -70 \\
\hline Lactic acid bacteria, cfu g ${ }^{-1}$ & $8.6 \times 10^{7}$ & $2.1 \times 10^{6}$ & $1.8 \times 10^{7}$ \\
\hline Enterobacteria, cfu g $^{-1}$ & $1.0 \times 10^{3}$ & $6.2 \times 10^{4}$ & $7.8 \times 10^{5}$ \\
\hline Yeasts, cfu g ${ }^{-1}$ & $6.6 \times 10^{5}$ & $1.1 \times 10^{5}$ & $1.5 \times 10^{6}$ \\
\hline Moulds, cfu g-1 & $6.4 \times 10^{3}$ & $8.2 \times 10^{3}$ & $1.0 \times 10^{5}$ \\
\hline
\end{tabular}

IVOMD = In vitro organic matter digestibility - pepsin-cellulase method calculated with the general equation of Huhtanen et al. (2006); MP = metabolizable protein; PBV = protein balance in the rumen (Luke 2019); cfu = colony forming units

After 28 days ensiling period, the DM concentration of the solid fraction of ensiled carrot was on average 84.3 and that of the liquid fraction $60.5 \mathrm{~g} \mathrm{~kg}^{-1}$ (Table 3). The focus was on the preservation quality so we only measured WSC and some fermentation end-products from the two fractions and they represented 0.108 of solid fraction DM and 0.328 (both out of 1) of the liquid fraction DM in the control and LAB treated samples, respectively. For FA treated carrot, the analyses recovered 0.413 of solid fraction DM and for liquids the recovery was 1.048.

In general, there were very few differences between $L A B s$ and the control treatment (Table 3 ), but somewhat lower lactic $(p<0.01)$, acetic $(p=0.03)$ and butyric $(p=0.02)$ acid concentrations were found in the liquid fraction of $L A B$ compared to the control, and higher $\mathrm{pH}(p<0.01)$ in the solid fraction. Also DM contents of both solid $(p=0.01)$ and liquid $(p<0.01)$ fractions were higher in LAB treated than in control samples.

Treating the material with FA resulted in a totally different type of fermentation (Table 3), which was more restricted and dominated by ethanol formation $(p<0.01)$ with virtually no lactic acid $(p<0.01)$ but limited amount of acetic acid $(p<0.01)$ being produced. A sizeable amount of WSC was present after 28 days of fermentation $(p<0.01)$ in the solid fraction of FA treated carrot mass in comparison to the other additive treatments. Lower proportion of ammonia $\mathrm{N}$ in total $\mathrm{N}(p<0.01)$ was obtained in silages treated with FA after correction for the amount contributed by the additive. 
Table 3. Gas production (GP) during fermentation, and composition and fermentation quality of the solid and liquid fractions of ensiled carrot by-products in Experiment 1 ( $1.5 \mathrm{I}$ jars) after 28 days of fermentation

\begin{tabular}{|c|c|c|c|c|c|c|c|c|c|}
\hline & \multirow{2}{*}{ Control } & \multirow{2}{*}{ LAB1 } & \multirow{2}{*}{ LAB2 } & \multirow{2}{*}{ LAB3 } & \multirow{2}{*}{ FA } & \multirow{2}{*}{ SEM } & \multicolumn{3}{|c|}{$p$-value } \\
\hline & & & & & & & C LAB & CFA & LAB FA \\
\hline $\mathrm{GP}, \mathrm{ml} \mathrm{g}^{-1} \mathrm{DM}$ & 13.7 & 23.9 & 20.0 & 19.0 & 21.4 & 1.09 & $<0.01$ & $<0.01$ & 0.77 \\
\hline Liquid proportion ${ }^{1)}$ & 0.027 & 0.015 & 0.020 & 0.015 & 0.039 & 0.0048 & 0.09 & 0.12 & 0.03 \\
\hline \multicolumn{10}{|l|}{ Solid fraction } \\
\hline $\mathrm{DM}, \mathrm{g} \mathrm{kg}^{-1}$ & 81.1 & 85.4 & 83.1 & 84.7 & 87.3 & 0.95 & 0.01 & $<0.01$ & 0.02 \\
\hline $\mathrm{pH}$ & 3.37 & 3.42 & 3.41 & 3.45 & 3.68 & 0.014 & $<0.01$ & $<0.01$ & $<0.01$ \\
\hline Ammonia $\mathrm{N}, \mathrm{g} \mathrm{kg}^{-1} \mathrm{~N}$ & 55 & 58 & 56 & 56 & $27^{21}$ & 2.0 & 0.61 & $<0.01$ & $<0.01$ \\
\hline \multicolumn{10}{|l|}{ In DM, $\mathrm{g} \mathrm{kg}^{-1}$} \\
\hline WSC & 13.9 & 15.4 & 14.5 & 19.1 & 304.0 & 9.27 & 0.82 & $<0.01$ & $<0.01$ \\
\hline Ethanol & 36.6 & 38.3 & 38.3 & 40.1 & 95.7 & 4.22 & 0.65 & $<0.01$ & $<0.01$ \\
\hline Lactic acid & 172 & 158 & 175 & 152 & 1 & 80.9 & 0.22 & $<0.01$ & $<0.01$ \\
\hline Acetic acid & 40.0 & 40.6 & 38.7 & 32.6 & 7.7 & 1.18 & 0.08 & $<0.01$ & $<0.01$ \\
\hline Propionic acid & 1.7 & 1.9 & 1.7 & 1.8 & 4.1 & 0.10 & 0.60 & $<0.01$ & $<0.01$ \\
\hline Butyric acid & 0.9 & 0.8 & 0.8 & 0.9 & 0.9 & 0.02 & 0.42 & 0.11 & 0.01 \\
\hline \multicolumn{10}{|l|}{ Liquid fraction } \\
\hline $\mathrm{DM}, \mathrm{g} \mathrm{kg}^{-1}$ & 59.1 & 68.2 & 64.0 & 70.8 & 40.5 & 0.00 & $<0.01$ & $<0.01$ & $<0.01$ \\
\hline $\mathrm{pH}$ & 3.21 & 3.20 & 3.19 & 3.19 & 3.38 & 0.013 & 0.44 & $<0.01$ & $<0.01$ \\
\hline Ammonia $\mathrm{N}, \mathrm{g} \mathrm{kg}^{-1} \mathrm{~N}$ & 79 & 79 & 73 & 63 & $39^{21}$ & 5.3 & 0.25 & $<0.01$ & $<0.01$ \\
\hline \multicolumn{10}{|l|}{ In DM, $\mathrm{g} \mathrm{kg}^{-1}$} \\
\hline WSC & 4.7 & 5.4 & 4.5 & 7.8 & 823.0 & & & & \\
\hline Ethanol & 35.1 & 20.9 & 26.9 & 18.8 & 198.0 & 16.80 & 0.52 & $<0.01$ & $<0.01$ \\
\hline Lactic acid & 282 & 244 & 241 & 197 & 3 & 9.2 & $<0.01$ & $<0.01$ & $<0.01$ \\
\hline Acetic acid & 63.0 & 55.2 & 52.6 & 49.5 & 16.3 & 3.61 & 0.03 & $<0.01$ & $<0.01$ \\
\hline Propionic acid & 0.2 & 0.1 & 0.1 & 0.1 & 6.4 & 0.30 & 0.75 & $<0.01$ & $<0.01$ \\
\hline Butyric acid & 0.8 & 0.5 & 0.6 & 0.6 & 1.0 & 0.08 & 0.02 & 0.25 & $<0.01$ \\
\hline Yeasts $^{3)}$, cfu g ${ }^{-1}$ & $5.3 \times 10^{1}$ & $1.8 \times 10^{4}$ & $1.3 \times 10^{1}$ & $3.6 \times 10^{4}$ & $1.7 \times 10^{5}$ & $3.5 \times 10^{4}$ & 0.67 & $<0.01$ & $<0.01$ \\
\hline
\end{tabular}

The free-drainage method for liquid-solid separation of ensiled carrot was not very efficient, but FA treatment resulted in higher liquid separation than LAB. The differences in DM content of solid and liquid fractions were rather small (Table 3).

The cumulative production of fermentation gases clearly illustrates the differences in the type of fermentation among treatments (Fig. 1). All LAB treatments increased rate and final volume of gas produced compared to the control, while formation of gas from FA treated material had a longer lag phase, higher final volume of gas and did not reach a plateau during the 28-day observation period.

Hygienic quality of samples was evaluated by determining enterobacteria (Fig. 2), moulds (Fig. 3) and yeasts (Fig. 4) from the fresh product and after 2, 6, 14 and 28 days of ensiling. Microbial counts clearly decreased with time for all treatments. After 14 days, counts of all samples were below detection limit. Likewise, lower counts of yeasts were detected after ensiling. 


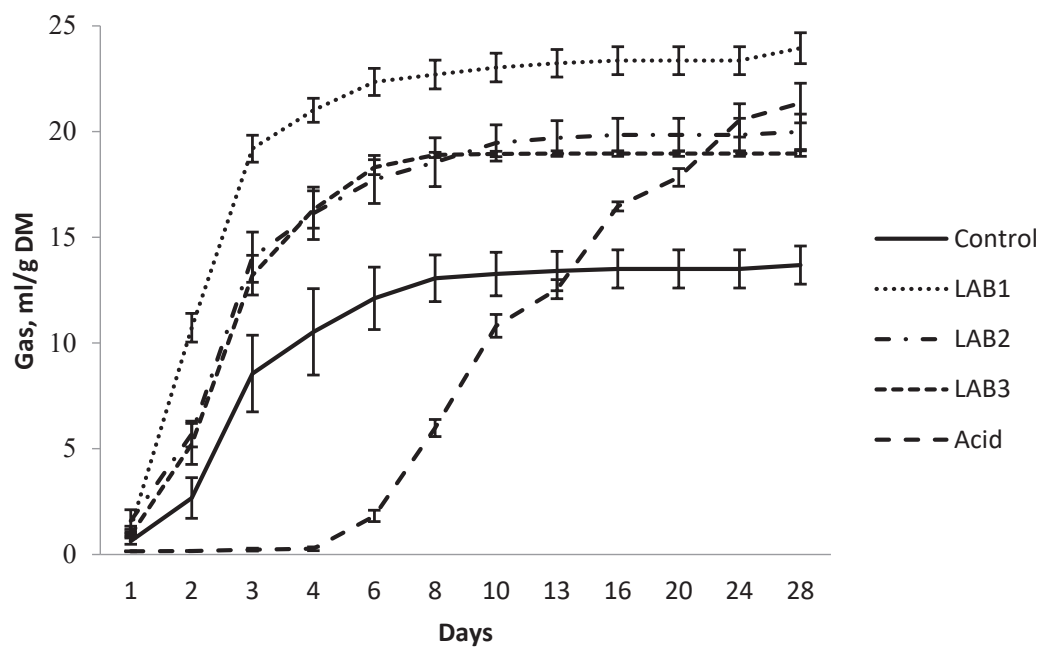

Fig. 1. Cumulative gas production curves from carrot by-product in Experiment $1(100 \mathrm{ml}$ glass bottles) using different additives during the ensiling process; $n=3$

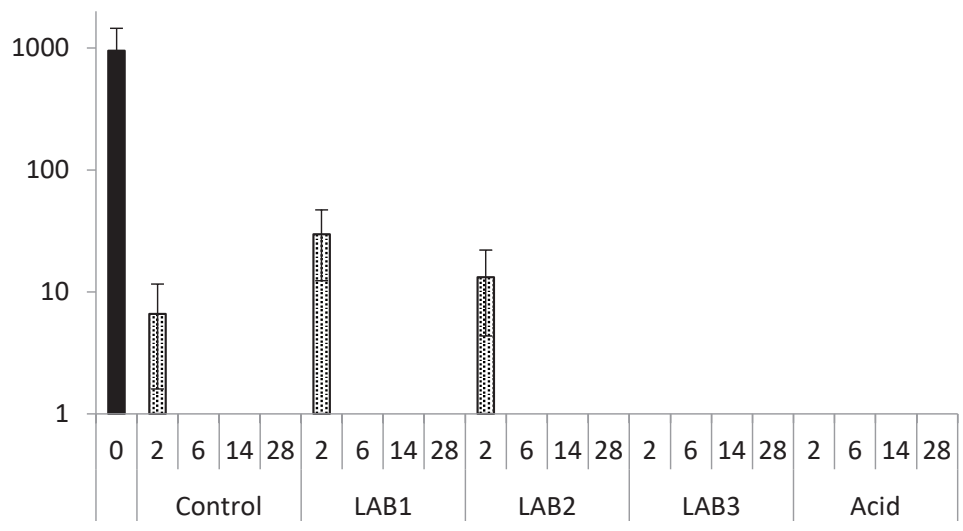

Fig. 2. Enterobacteria ( $\mathrm{cfu} \mathrm{g}^{-1}$, logarithmic scale) of carrot by-product in Experiment 1 (100 $\mathrm{ml}$ glass bottles) after different ensiling periods (days) and additive treatments

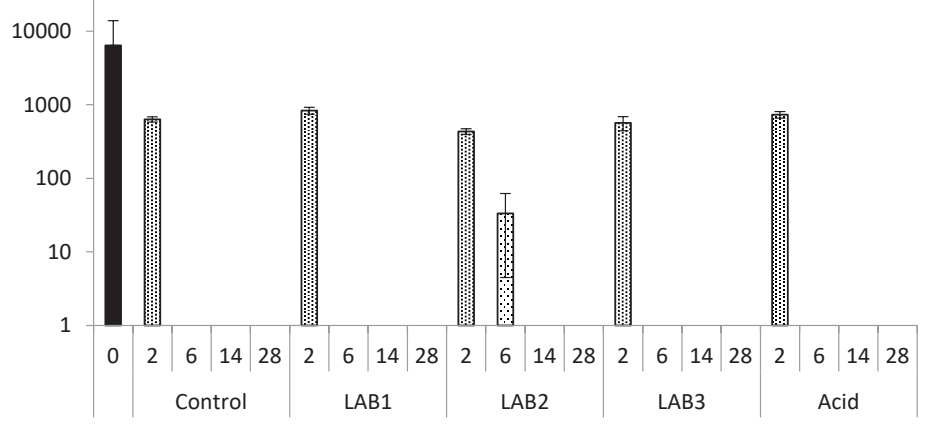

Fig. 3. Moulds (cfu g-1 ${ }^{-1}$ logarithmic scale) of carrot by-product in Experiment 1 (100 ml glass bottles) after different ensiling periods (days) and additive treatments

The fresh untreated and LAB treated carrot by-products spoiled already after 2 days, but stability was greatly improved by FA up to 10 days (Fig. 5). Ensiling slightly increased stability of control and LAB treated materials and slightly decreased that of FA resulting in a stability of 7 days for all treatments after a 28-day fermentation period, except for LAB3. 


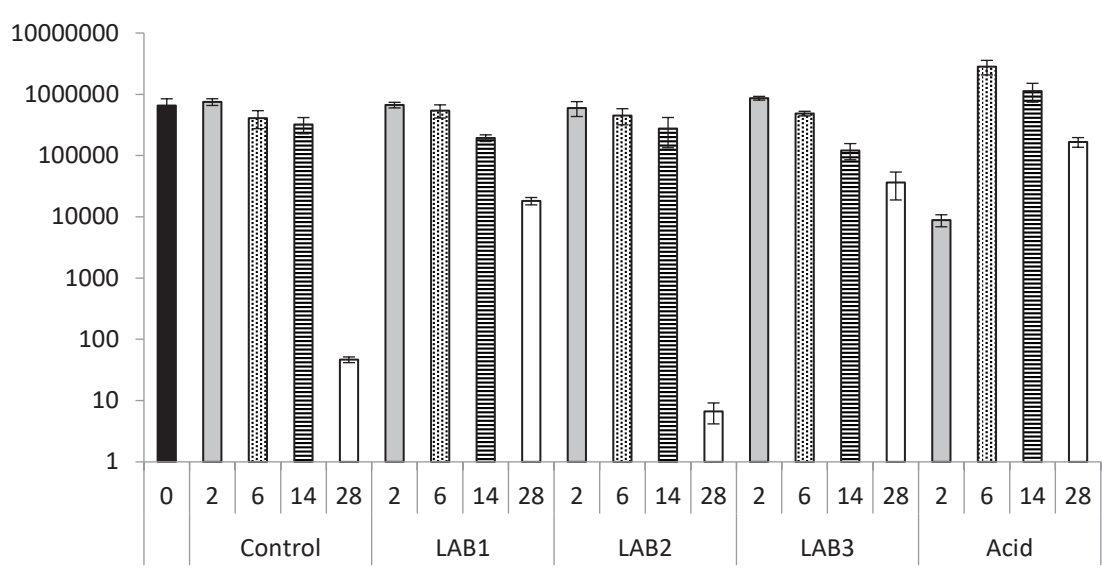

Fig. 4. Yeast (cfu g-1, logarithmic scale) of carrot by-product in Experiment $1(100 \mathrm{ml}$ glass bottles) after different ensiling periods (days) and additive treatments.

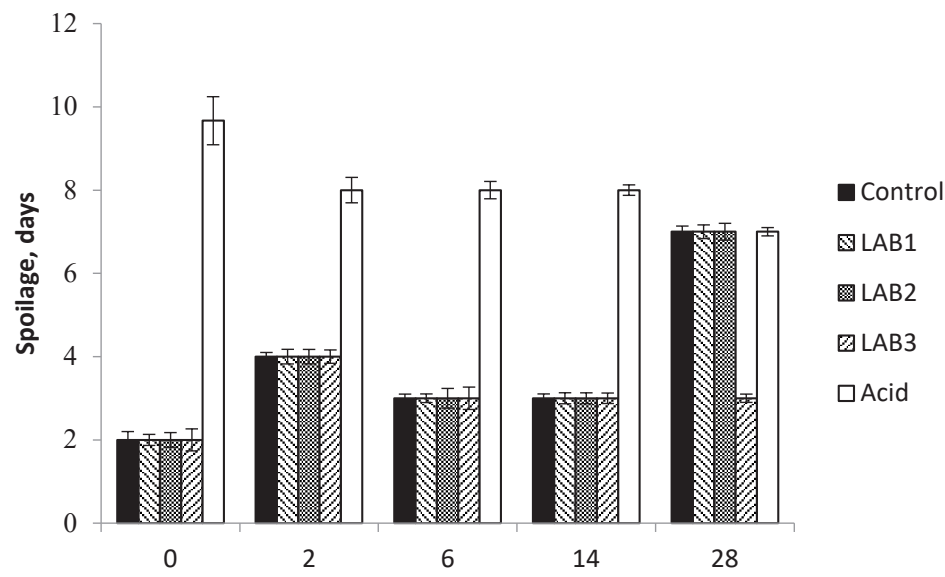

Fig. 5. Days until spoilage (through visual inspection) of carrot by-product in Experiment 1 ( $100 \mathrm{ml}$ glass bottles) after different ensiling periods (days) and additive treatments.

\section{Experiment 2}

In Exp. 2, the DM concentration of carrot by-products prior to ensiling was lower than those in Luke (2019) Feed Tables ( 73 vs. $120 \mathrm{~g} \mathrm{~kg}^{-1}$ ) containing less ash (70 vs. $80 \mathrm{~g} \mathrm{~kg}^{-1} \mathrm{DM}$ ) and CP (67 vs. $100 \mathrm{~g} \mathrm{~kg}^{-1}$ DM). Content of WSC was lower and neutral detergent fibre higher in Exp. 2 than in Exp. 1 (Table 2).

There was a higher concentration of ash, WSC, lactic, acetic $(p<0.01)$ and propionic $(p=0.03)$ acids for ensiled carrot by-product with pieces than in the carrot without pieces (Table 4). All treatments showed extensive fermentation with low pH (on average 3.71) after the 3-week fermentation period. Formic acid resulted in greater $(p<0.01)$ $\mathrm{DM}$ and $\mathrm{CP}$ content of both carrot by-product types compared to other treatments. The use of FA efficiently reduced $(p<0.01)$ conversion of WSC into lactic, acetic, propionic and butyric acids compared to control and LAB1, but resulted in very high $(p<0.01)$ ammonia $N$ proportion of total $N$. There was no effect $(p>0.05)$ of LAB1 treatment compared to control in the parameters evaluated except for weight losses $(p=0.03)$, which increased with the addition of the inoculant. Ensiling had an effect on microbial quality of the silage since counts of yeasts, moulds and enterobacteria decreased for all treatments including control. Formic acid decreased LAB in ensiled carrot by-products compared to the other treatments (Table 4).

Fresh samples (before ensiling) deteriorated in two to three days during aerobic phase (Fig. 6). The stability of the FA treated materials was slightly prolonged, but all samples deteriorated quickly compared to Exp. 1 . In the ensiled materials, FA delayed spoilage up to 3 days; control and LAB1 were deteriorated more quickly. 
Table 4. Type of raw material and additive effects on the composition and quality of ensiled carrot by-products in Experiment 2 (10 kg fresh matter per bucket) after 21 days in room temperature

\begin{tabular}{|c|c|c|c|c|c|c|c|c|c|c|c|}
\hline & \multicolumn{3}{|c|}{ Carrot with pieces } & \multicolumn{3}{|c|}{ Carrot without pieces } & \multirow{2}{*}{ SEM } & \multicolumn{4}{|c|}{$p$-value } \\
\hline & Control & LAB1 & FA & Control & LAB1 & FA & & $\mathrm{R}$ & C LAB1 & CFA & LAB1 FA \\
\hline $\mathrm{DM}, \mathrm{g} \mathrm{kg}^{-1}$ & 60 & 61 & 75 & 60 & 64 & 75 & 0.9 & 0.46 & 0.17 & $<0.01$ & $<0.01$ \\
\hline \multicolumn{12}{|c|}{ Chemical composition, $\mathrm{g} \mathrm{kg}^{-1} \mathrm{DM}$} \\
\hline Ash & 88 & 87 & 67 & 79 & 78 & 66 & 0.7 & $<0.01$ & 0.47 & $<0.01$ & $<0.01$ \\
\hline $\mathrm{CP}$ & 72 & 73 & 78 & 71 & 71 & 82 & 0.6 & 0.95 & 0.62 & $<0.01$ & $<0.01$ \\
\hline WSC & 10 & 11 & 394 & 6 & 6 & 245 & 1.7 & $<0.01$ & 0.89 & $<0.01$ & $<0.01$ \\
\hline $\mathrm{pH}$ & 3.60 & 3.58 & 3.80 & 3.73 & 3.77 & 3.78 & 0.012 & $<0.01$ & 0.73 & $<0.01$ & $<0.01$ \\
\hline Ammonia $\mathrm{N}, \mathrm{g} \mathrm{kg}^{-1} \mathrm{~N}$ & 29 & 28 & $150^{\mathrm{a}}$ & 29 & 28 & $165^{\mathrm{a}}$ & 6.1 & 0.51 & 0.82 & $<0.01$ & $<0.01$ \\
\hline \multicolumn{12}{|c|}{ Fermentation acids, $\mathrm{g} \mathrm{kg}^{-1} \mathrm{DM}$} \\
\hline Lactic acid & 192 & 190 & 2 & 139 & 141 & 6 & 3.0 & $<0.01$ & 0.98 & $<0.01$ & $<0.01$ \\
\hline Acetic acid & 53.1 & 52.3 & 5.9 & 33.6 & 35.7 & 6.4 & 0.70 & $<0.01$ & 0.61 & $<0.01$ & $<0.01$ \\
\hline Propionic acid & 4.7 & 4.5 & 0.9 & 4.0 & 4.2 & 0.9 & 0.09 & 0.03 & 0.92 & $<0.01$ & $<0.01$ \\
\hline Butyric acid & 0.34 & 0.33 & 0.27 & 0.33 & 0.31 & 0.27 & $<0.01$ & 0.41 & 0.14 & $<0.01$ & $<0.01$ \\
\hline Weight loss, \% & 0.21 & 0.63 & 0.25 & 0.38 & 0.46 & 0.13 & 0.094 & 0.65 & 0.03 & 0.30 & $<0.01$ \\
\hline Yeast $^{11}$, cfu g $^{-1}$ & $<1.0 \times 10^{3}$ & $4.8 \times 10^{3}$ & $6.1 \times 10^{3}$ & $2.8 \times 10^{3}$ & $<1.0 \times 10^{3}$ & $<1.0 \times 10^{3}$ & $1.2 \times 10^{3}$ & 0.05 & 0.42 & 0.20 & 0.59 \\
\hline $\begin{array}{l}\text { Lactic acid bacteria, } \\
\text { cfu g }^{-1}\end{array}$ & $2.0 \times 10^{8}$ & $2.2 \times 10^{8}$ & $1.8 \times 10^{4}$ & $1.5 \times 10^{8}$ & $1.1 \times 10^{8}$ & $3.1 \times 10^{5}$ & $2.7 \times 10^{7}$ & 0.06 & 0.77 & $<0.01$ & $<0.01$ \\
\hline
\end{tabular}

For treatment explanations, see Table 1. SEM = Standard error of the mean; $R=$ Carrot with pieces versus Carrot without pieces; $C$ LAB1 $=$ Control versus $L A B 1 ; C$ FA $=$

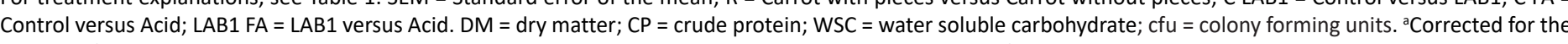
amount of ammonia in the additive, the uncorrected values were 229 and $239 \mathrm{~g}$ ammonia $\mathrm{N}$ per kg total $\mathrm{N}$ for carrot by-products with and without pieces, respectively. Moulds and Enterobacteria were below detection limits of $1.0 \times 10^{3}$ and $1.0 \times 10^{1}$, respectively. 


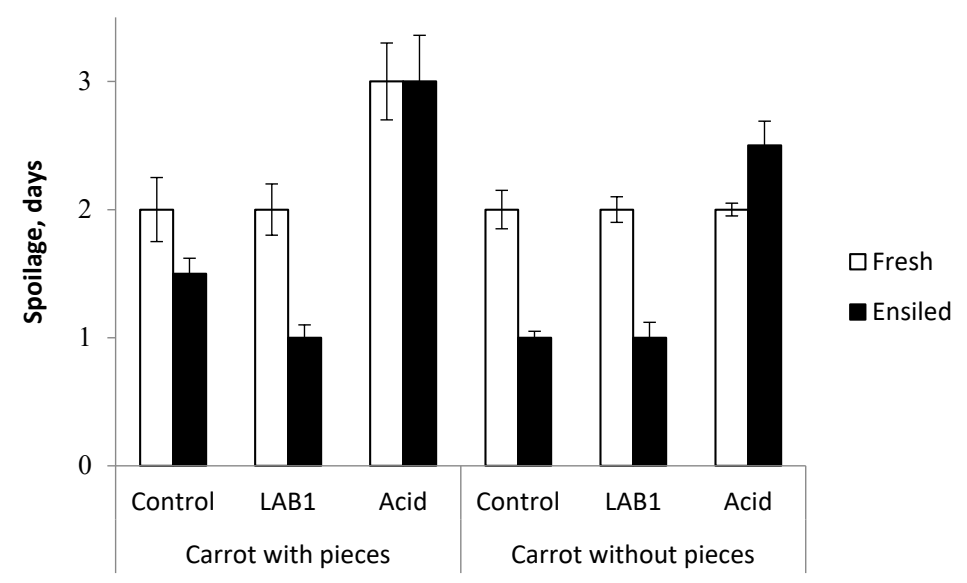

Fig. 6. Days until spoilage (through visual inspection; days) of fresh and ensiled carrot by-products in Experiment 2 (10 kg fresh matter per bucket) according to raw material types and additive treatments.

\section{Discussion}

The composition of the carrot by-product raw materials was rather well comparable to the reference values for whole carrots (Luke 2019). The lower content of DM in the carrot by-products is due to the processing of material including addition of water. Hygienic quality of the raw material in Exp. 1 was on average greater than in Exp. 2, presenting lower amount of moulds, Enterobacteria and yeasts. In Exp. 2, the hygienic quality of carrots without pieces was poorer than that with pieces, probably due to the longer storage period of it prior to sampling and ensiling.

Carrots are highly palatable and digestible (Alabran and Mabrouk 1973, Bakshi et al. 2016), and large amount of the DM was in the form of WSC in both experiments. Such a material is readily fermentable, and indeed, the fermentation of the untreated and $L A B$ treated material was very strong and resulted in vigorous gas production in the beginning of the ensiling period, very low $\mathrm{pH}$ values and high concentrations of fermentation acids in the ensiled material. The FA treatment resulted in a completely different fermentation profile of the carrot by-product silage compared to the other treatments. Basically, the fermentation was effectively restricted by FA with high concentration of residual WSC in the ensiled material during the short 3 to 4 week ensiling period. The cumulative gas production measured in Exp.1 showed the restriction of fermentation at the beginning of ensiling period by FA treated silages, but the gas production increased gradually and final gas volume was higher than in other silages except LAB1. FA was the only treatment that did not reach a plateau during the observation period. On the other hand, FA resulted in a high formation of ethanol indicating a yeast type of fermentation, which is common in e.g. sugar cane silages also containing high amounts of WSC (Pedroso et al. 2005, Carvalho et al. 2014).

The higher ammonia concentration of the FA treated silages originated partly from the additive. When corrected for the amount of ammonia applied in the additive, the levels in Exp. 1 where decreased to a level even lower than in other treatments, but remained high in Exp. 2. It is possible that this method leads into over-correction because part of the added ammonia may evaporate during preparation of silages and processing of samples, but it is difficult to estimate the potential losses. Although the proportion of ammonia $\mathrm{N}$ in total $\mathrm{N}$ was very high and would result in judgement of poor preservation based on guidelines prepared for grass silage (Wilkinson 1990), it must be noted that the absolute amount of ammonia was not that high as the total $\mathrm{N}$ concentration in carrot material was relatively low.

The possibilities to prolong aerobic stability by the use of additives have received a lot of attention in grass and maize silages. Heterofermentative LAB producing acetic acid has resulted in prolonged stability, but may simultaneously lead to increased DM losses during the ensiling period (Reich and Kung 2010). Although FA is not effective against yeasts, FA treatment has previously resulted in improved aerobic stability of grass silages (see e.g. Seppälä et al. 2016). In the current experiment, the advantages of using FA disappeared by day 28 of fermentation, which may be related to accumulation of acetic acid in the other silages, as it is known to improve aerobic stability.

A general challenge with the carrot by-products is the dilute nutrient content due to high moisture content of them. Dewatering would be a logical first step in further processing of the by-products, and ensiling the dry residue would probably be more successful than that of the original moist product. According to Bakshi et al. (2016), 
after extraction of juice, approximately one-third of the raw material remains as pulp and contains $\mathrm{CP}$ concentration of $80 \mathrm{~g} \mathrm{~kg}^{-1}$ DM. Furthermore, according to Bakshi and Wadhwa (2013), the digestion kinetic parameters for DM revealed that about $97 \%$ of the carrot pulp is degradable, with very high effective and true degradabilities and low rumen fill, resulting in high potential DM intake. Companies therefore need to consider if it is profitable to invest in such processing, but in that case, markets need to be found for two rather than one by-product type.

A practical solution could be to use fresh by-product for cattle, and to use acid-based silage additives to improve the stability for reduced delivery intervals. Carrot mass (fresh or ensiled) could also be a good source of digestible fibre for finishing pigs and gestating sows in extensive pig rearing systems. Liquid effluent from carrot mass could create a major practical problem. Co-ensiling carrots with some absorbents (Laflamme 1992, Adler et al. 2017) such as straw, hay, cereals or other dry by-products could alleviate this problem, but increased logistic costs and decreased feed value need to be considered although benefits in the ensiling process may be achieved.

A novel idea would be to prepare a liquid feed from fresh or ensiled carrot mass that could be used for pigs. Although the liquid fraction has certain interesting qualities as a pig feed, it has a very low DM content and it may be difficult to ensure stable and sufficient supply to large pig units. In our experimental setting, the yield of liquid fraction remained very low, but that could be increased by technical solutions as demonstrated e.g. by Franco et al. (2019) in preparing juice from different quality grass silages using several pressing methods.

By-products such as carrot derived feed materials may also have positive effects in feeding of livestock as it is readily consumed and is rich in e.g. carotene. In case of fermented products, LAB and added organic acids may stabilize the liquid feed prepared for pigs and have positive effects in the intestinal health of pigs. If a vegetable company markets by-products as feeds, EU legislation requires them to register to ensure safety of the feed, which is the responsibility of the feed producer.

\section{Conclusions}

Ensiling of carrot by-products was very challenging due to high moisture and extensive fermentation, but the use of formic acid-based additive restricted the lactic acid fermentation during a short (less than 1 month) ensiling period and resulted in clearly higher residual water soluble carbohydrate concentration. However, at the same time formic acid stimulated ethanol production. Only minor effects could be detected from using different lactic acid bacteria inoculants compared to control. Spoilage of the fresh carrot by-product was remarkably delayed by applying formic acid-based additive particularly in Exp. 1.

\section{Acknowledgements}

These results have been produced as part of Sivuhyöty-project with funding from the Finnish Ministry of Environment (RAKI-program).

\section{References}

Adler, S., Slizyte, R., Juvonen, R., Alakomi, H.-I., Rubasheuski, V. \& Ebbesvik, M. 2017. Ensilering av frasorterte poteter og gulrøtter - Fra tap til fôr med tilleggsverdi. NORS $\varnothing$ K Report Vol. 2 / Nr. 4/2017. 34 p. ISBN 978-82-8202-035-0.

Alabran, D.M. \& Mabrouk, A.M. 1973. Carrot flavor. Sugars and free nitrogenous compounds in fresh carrots. Journal of Agricultural and Food Chemistry 21: 205-208. https://doi.org/10.1021/jf60186a020

Antone, U., Zagorska, J., Sterna, V., Jemeljanovs, A., Berzins, A. \& Ikauniece, D. 2015. Effects of dairy cow diet supplementation with carrots on milk composition, concentration of cow blood serum carotenes, and butter oil fat-soluble antioxidative substances. Agronomy Research 13: 879-891.

Arco-Pérez, A., Ramos-Morales, E., Yáñez-Ruiz, D.R., Abecia, L. \& Martín-García, A.I. 2017. Nutritive evaluation and milk quality of including of tomato or olive by-products silages with sunflower oil in the diet of dairy goats. Animal Feed Science and Technology 232: 57-70. https://doi.org/10.1016/j.anifeedsci.2017.08.008

Bakshi, M.P.S. \& Wadhwa, M. 2013. Nutritional evaluation of cannery and fruit wastes as livestock feed. The Indian Journal of Animal Science 83: 1198-1202.

Bakshi, M.P.S., Wadhwa, M. \& Makkar. H.P.S. 2016. Waste to worth: vegetable wastes as animal feed. CAB Reviews 11: 1-26. https://doi.org/10.1079/PAVSNNR201611012

Carvalho, B.F., Ávila, C.L.S., Pinto, J.C., Neri, J. \& Schwan, R.F., 2014. Microbiological and chemical profile of sugar cane silage fermentation inoculated with wild strains of lactic acid bacteria. Animal Feed Science and Technology 195: 1-13. https://doi. org/10.1016/j.anifeedsci.2014.04.003 
Franco, M., Hurme, T., Winquist, E. \& Rinne, M. 2019. Grass silage for biorefinery - A meta-analysis of silage factors affecting liquid-solid separation. Grass and Forage Science. https://doi.org/10.1111/gfs.12421

Huhtanen, P., Nousiainen, J. \& Rinne, M. 2006. Recent developments in forage evaluation with special reference to practical applications. Agricultural and Food Science 15: 293-323. https://doi.org/10.2137/145960606779216317

Karak, T., Bhagat, R.M. \& Bhattacharyya, P. 2012. Municipal solid waste generation, composition, and management: the world scenario. Critical Reviews in Environmental Science and Technology 42: 1509-1630. https://doi.org/10.1080/10643389.2011.569871

Laflamme, L.F. 1992. Carrot/grass silage as cattle feed. Canadian Journal of Animal Science 72: 441-443. https://doi.org/10.4141/ cjas92-056

Luke 2019. Feed Tables and Nutrient Requirements. www.luke.fi/feedtables. Accessed 14 May 2019.

Meneses, M., Megías, M.D., Madrid, J., Martínez-Teruel, A., Hernández, F. \& Oliva, J. 2007. Evaluation of the phytosanitary, fermentative and nutritive characteristics of the silage made from crude artichoke (Cynara scolymus L.) by-product feeding for ruminants. Small Ruminant Research 70: 292-296. https://doi.org/10.1016/j.smallrumres.2006.05.008

Muller, P.G., Pigden, W.J. \& Graham, W.W. 1984. Economic, nutritional and physiological evaluation of feeding food processing waste products to farm livestock. Food Processing, Distribution and Retailing Contract Research Program. Marketing and Economics Branch, Agriculture Canada, Ottawa, ON. https://tind-customer-agecon.s3.amazonaws.com/b4ceb98c-bf2f-4ff9-9b8b44e6ff150793? response-content-disposition=inline\%3B\%20filename\%2A\%3DUTF-8\%27\%27aafc-mewp-06-84.pdf\&responsecontent-type=application\%2Fpdf\&AWSAccessKeyld=AKIAXL7W7Q3XHXDVDQYS\&Expires=1561632292\&Signature=gzolwRdCrM kZ9LtOYfmysKp\%2BQ2M\%3D

Nalęcz-Tarwacka, T., Karaszewska, A. \& Zdziarski, K. 2003. The influence of carrot addition to cow's ration on the level of vitamins and fatty acids in cow milk. Polish Journal of Food Nutrition Sciences 12: 53-56.

Orosz, Sz. \& Davies, D.R. 2015. Short and long term storage of wet by-products fed by ruminants. In: Daniel, J.L.P., Morais, G., Junges D. \& Nussio, L.G. (eds.). Proceedings of the XVII Int. Silage Conf. Piracicaba, Brazil, 1-3 July 2015. p. 200-242.

Pedroso, A.F., Nussio, L.G., Paziani, S.F., Loures, D.R.S., Igarasi, M.S., Coelho, R.M., Packer, I.H., Horii, J. \& Gomes, L.H. 2005. Fermentation and epiphytic microflora dynamics in sugar cane silage. Scientia Agricola 62: 427-432. https://doi.org/10.1590/S010390162005000500003

Reich, L.J. \& Kung, L. Jr. 2010. Effects of combining Lactobacillus buchneri 40788 with various lactic acid bacteria on the fermentation and aerobic stability of corn silage. Animal Feed Science and Technology 159: 105-109. https://doi.org/10.1016/j.anifeedsci.2010.06.002

Rust, S.R. \& Buskirk, D.B. 2008. Feeding carrots or sugar beets to cattle. Cattle Call 13: 1-2. http://msue.anr.msu.edu/uploads/236/58572/FeedingCarrotsorSugarBeets.pdf. Accessed 22 November 2018.

Schader, C., Muller, A., Scialabba, N. El-H., Hecht, J., Isensee, A., Erb, K.-H., Smith, P., Makkar, H.P.S., Klocke, P., Leiber, F., Schwegler, P., Stolze, M. \& Niggli, U. 2015. Impacts of feeding less food-competing feedstuffs to livestock on global food system sustainability. Journal of the Royal Society Interface 12: 1-12. https://doi.org/10.1098/rsif.2015.0891

Seppälä, A., Heikkilä, T., Mäki, M. \& Rinne, M. 2016. Effects of additives on the fermentation and aerobic stability of grass silages and total mixed rations. Grass and Forage Science 71: 458-471. https://doi.org/10.1111/gfs.12221

Stenmarck, Å., Jensen, C., Quested, T. \& Moates, G. 2016. Estimates of European food waste levels. European Commission (FP7), Coordination and Support Action. Stockholm, Sweden. https://www.eu-fusions.org/phocadownload/Publications/ Estimates\%20 of\%20European\%20food\%20waste\%20levels.pdf. Accessed 26 May 2018.

Vasta, V., Nudda, A., Cannas, A., Lanza, M. \& Priolo, A. 2008. Alternative feed resources and their effects on the quality of meat and milk from small ruminants. Animal Feed Science and Technology 147: 223-246. https://doi.org/10.1016/j.anifeedsci.2007.09.020

Wadhwa, M. \& Bakshi, M.P.S. 2013. Utilization of fruit and vegetable wastes as livestock feed and as substrates for generation of other value-added products. FAO Publication 2013/04. H.P. Makkar Technical Editor. http://www.fao.org/docrep/018/i3273e/ i3273e.pdf. Accessed 26 May 2018.

Wilkinson, J.M. 1990. Silage UK, Sixth Edition. Marlow, UK, Chalcombe Publications. 185 p. 